\title{
「薬と健康の週間」に行った薬局前待合室での 「やさしいお薬講座」の試み
}

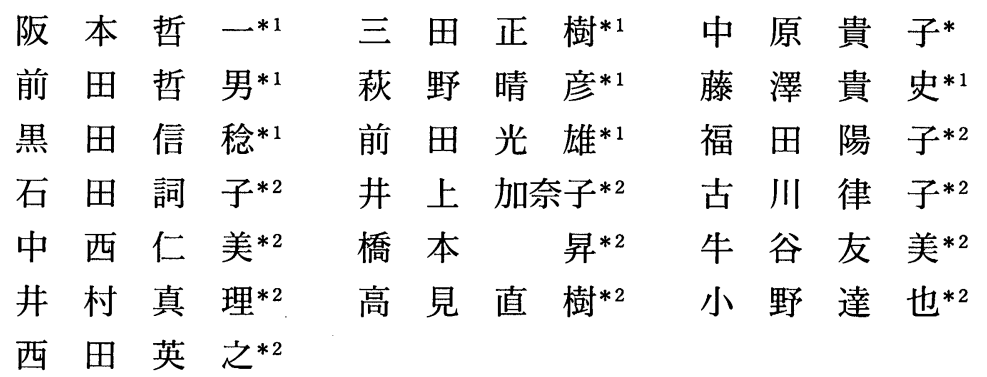

目的

近年の種々の薬害の報道を初めとする薬滆の副作 用に対する社会的関心が高まり、自分に処方され ている薬骭自体に対する関心が持たれ始めている。 また平成 9 年 4 月の薬唷師法改正による服薬指導 の義務化、同年 9 月の健康保険法改正による薬骩 費の一部自己負担化といった社会情勢も変化して きている。この様な状況に対処するため当院では 毎年 10 月 17 日から 24 日に行なわれている「薬 と健康の週間」にあわせて内科と薬骩科が共同し て患者教室として薬局前待合室に扔いて「やさし いお薬講座」を平成 8 年より行っている。この集 団患者指導の試みについて報告する。

\section{方法}

毎年 10月17日から 24 日にかけて「薬と健康 の週間」 (厚生省、都道府県、日本薬刘師会主催) が行われている。この期間中に 2 回（月曜日と木 曜日の午後）にわたって同内容のものを薬局前待 合室にて「やさしいお薬講座」として講義を行っ
た。講義は以下の内容でおこなった。内科医によ る「薬はどうして効くのか」(平成 8 年度は降圧 㑉、平成 9 年度は喘息薬を例にとって薬郕の作用 機序と処方の際の考え方について、20 分) 薬剤 師による「薬の正しい服用の仕方」(薬の吸収の され方、服用の仕方等、20 分）薬剤師による 「病院薬郕師の仕事」(当院薬郕科にて行ってい る服薬指導、病棟活動についての紹介、20 分) 以上の 3 講義、計 1 時間を行った。また平成 9 年 度はこれに加えて薬䯇師による「お薬Q＆A」（普 段患者さんよりよく聞か冯る筫問、疑問点につい ての解説、10 分）、及び製薬会社のMRにも協力 してもらい、「正しい目薬のさし方、湿布薬の貼 り方」の実演も加えて行った。理解を深めて鿓う 為、上記講義内容に即した 12 ページのパンフレ ットを作成し来られた方全員に配布した。フロア 一利用の講義でめるため、この間患者さんは出入 り自由とし、終了した時点でおられた方にたいし てアンケート調査を行った。

また期間中、薬局前の待合室にて薬の吸収のされ 方、服用の仕方等を模造紙に書きポスター展示を 行った。

\footnotetext{
*1 石川島播磨重工業健康保険組合播磨病院内科 干 678-0031 相生市旭 3-5-15

*2 石川島播磨重工業健康保険組合播磨病院薬剤科
} 


\section{結果}

平成8年度の場合は、途中出入りがあったが常時 2 0〜30人の患者さんが聴講しておられた。終了 後、自分の服用している薬に対しての質問があり、 医師、薬削師が各々対応した。終了後、外来、病 棟、薬局での医師、薬夙師に対する薬剤に対する 啠問が明らかに增え、「閏きたかった。」、「ま た開催して欲しい。」との要㕵か強く好評であっ た。その為、今後毎年行うこととなった。 平成9年度も途中出入りがあったが常時 $30 \sim 40$ 人の患者さんが聴講しておられ、前年度とそう変 りはなかった。しかし「正しい目薬のさし方、湿 布薬の貼り方」の実演は、人目を引いたのか患者 さんの集まりが急に增え、70〜80人集まり、

午前と午後の外来診察の間の時間としては非常に 患者さんが集まり盛況であった。

講義終了時にアンケートをとった。協力していた だいた方は 26 名であった。講義の内容は $90 \%$ 以上、展示及びパンフレットは $85 \%$ 以上はほほ 理解できた様であった。また $95 \%$ 以上の人がま た来年も受講したいと答えていた。また薬に関し て最も関心のあることを答えてもらったところ圧 倒的に副作用（6 4.3\%）についてであり、薬効 は僅か $17.9 \%$ あった。

\section{考察}

当科では平成 6 年 10 月より内科病棟総回診時に 薬剤師も同行しデイスカションに加わってもらっ たり、適宜医薬品情報提供をうけたりといった試 みを通じて協力して治療を行う努力を進めている。 また高血圧教室、腎臓病教室、糖尿病教室といっ た集団患者指導においても医師、栄養士、看護婦 のみならず、薬剤師にも参加協力してもらい患者 指導を行う努力を進めている。その一環として個々 の患者さんに対する服薬指導と平行し、とくに誰 でも気軽に聴きに来れる薬局前待合室でこの様に 医師と薬郕師が協力して集団患者指導を行った。 結果として多くの患者さんに聴講してもらう事が でき、アンケートでも非常に好評であった。この 企画は、患者さんの薬骩、薬物療法の理解を進め るのみならず、医師・薬戍師の協力のもとで治療 がなされている事を理解していただく機会の一つ
として非常に意義あるものと考えられた。この様 になんらかの形で医師も薬骩師による服薬指導に 関与していく事はその効果や患者さんの理解や信 頼を增す上で重要であると考えられた。

「薬と健康の週間」は1950年より始められ、 各地で日本薬威師会を中心にしてさまさまな催し が行なわれている。この様な機会を利用して、こ の様な医師も協力した企画を行う事は本年から義 務化された薬骩師による服薬指導をさらに有効に 機能させる様に発展させる一つの試みとして有意 義であったと考え報告した。 